\title{
COMMUNICATION OF JOB-RELATED INFORMATION AND WORK- FAMILY CONFLICT IN DUAL-CAREER COUPLES
}

\author{
BEDELIA THEUNISSEN \\ LJ VAN VUUREN \\ DELÈNE VISSER \\ Programme in Industrial Psychology \\ Department of Human Resource Management \\ Rand Afrikaans University
}

\begin{abstract}
It is known that work-family conflict is a determinant of marital dissatisfaction. The goal of this study was to determine whether inadequate communication regarding the sharing of job-related information between dual-career spouses contributes to marital dissatisfaction. The Work Perception Questionnaire (WPQ) was designed and administered to obtain information on dimensions that 80 dual-career couples (married or in co-habitation) perceived to contribute to marital conflict and that have an impact on the quality of their relationships. The main findings indicated that male partners experienced more marital conflict than their female partners if they did not have adequate job-related information about their partner's work. However, the findings for the female partners were nonsignificant. The implications of the findings are discussed.
\end{abstract}

\section{OPSOMMING}

Dit is algemeen bekend dat werk- en gesinskonflik ' $n$ oorsaak van huweliksontevredenheid is. Die doel van hierdie studie was om te bepaal of ontoereikende kommunikasie oor werksverwante inligting tussen gades in dubbelloopbaanverhoudings ' $n$ bydraende faktor tot huweliksontevredenheid is. Die Werk Persepsie Vraelys (WPV) is ontwerp en toegepas ten einde inligting te versamel rakende sekere dimensies wat volgens die persepsies van 80 dubbelloopbaanpare (wat getroud is of saamwoon) aanleiding gee tot huwelikskonflik en wat moontlik ' $\mathrm{n}$ impak op die gehalte van hul verhouding mag hê. Die belangrikste bevinding was dat manlike gades meer huwelikskonflik ervaar indien hul gades nie werksverwante inligting met hulle deel nie. Die resultate vir vroulike gades was egter nie beduidend nie. Die implikasies van die resultate word bespreek.

The past decades have witnessed dramatic changes in the way family life is viewed by organisations and organisations are showing a growing interest in work and family issues. Gabarro (1992, p. 530) proposed some reasons why organisations are becoming interested in these issues. Firstly, the work-force demographics are changing. Talent and skills were always freely available and people were willing to make the traditional sacrifices for success, such as travel, overtime and relocation. Organisations now have difficulties to retain talent due to the competitive nature of the economy. Many organisations use progressive family policies as a means of competing for employees. Secondly, employee perceptions are changing. Women and men are realising the importance of both work and family - thus people identify employers that will allow them to act responsibly toward their families and still satisfy their career ambitions. Lastly, organisations have realized that inflexibility may have an adverse effect on productivity, such as higher levels of stress, greater absenteeism and lower job satisfaction. These changes have an impact on the way in which relationships are viewed and the way careers and family issues are integrated to obtain a satisfying and economically prosperous life.

Economic pressures of inflation and poverty are forcing women to take a more active role outside the home and to pursue full-time careers. The economy needs the most competent and productive work force in order to remain globally competitive. However, the same work force must provide adequate care for their families at home (Gabarro, 1992, p. 529). The increase in the number of families with two working spouses has made traditional approaches to the coordination of work and family lives inappropriate. In other words, the traditional division of chores between partners is no longer appropriate (Smith, 1997, p. 229). Women are increasingly being forced to deal with job-related demands that limit their performance of family roles. Men are becoming

Requests for copies should be addressed to: LJ van Vuuren, Department of Human Resource Management, RAU University, PO Box 524, Auckland Park, 2006 more involved with their families and their priorities may even be shifting away from work. Together, these trends result in increased levels of work-family conflict as men and women try to balance conflicting work and family demands.

Work-family conflict is an important source of stress for individuals and organisations alike and has been linked to negative consequences, some severe. These include increased health risks for employed spouses, poorer performance in both roles (at work and home), absenteeism, turnover, poor morale and reduced life satisfaction (Duxbury \& Higgins, 1991; Thomas \& Ganster, 1995). These dysfunctional, negative consequences highlight the importance of further understanding the interrelationship between work and family. An imbalance between these two domains may even lead to marital dissatisfaction or marital distress (Sumer \& Knight, 2001, p. 659).

A substantial amount of research has been conducted regarding various issues of work-family conflict (Duxbury \& Higgins, 1991; Frone, Russel \& Cooper, 1992; Ganster \& Schaubroeck, 1991; Greenhaus \& Beutell, 1985; Netemeyer, Boles \& MacMurrain, 1996; Rapoport \& Rapoport, 1973; Rapoport \& Rapoport, 1976; Sumer \& Knight, 2001; Thomas \& Ganster, 1995). An important issue that has, however, not been well researched, is the role of inadequate communication of jobrelated information and the consequences thereof for workfamily conflict. It can be postulated that couples that have factual information about their spouse's daily routine, office setup, colleagues and other work-related issues, may manage their work and family lives better and may even experience more satisfaction at work and home.

The aim of this research is to analyse whether a link exists between the communication of job-related information and work-family conflict. This will be an exploratory study focusing on the problematic issues regarding dual-career couples, workfamily conflict and inadequate communication. 


\section{Dual-career/dual-earner couples}

Research indicates that the number of women entering the workforce is increasing and changing both work and family life (Carrell, Elbert \& Hatfield, 2000, p. 298). Greenhaus, Callanan and Godshalk (2000, p. 252) report that the traditional household where a husband works and a wife stays at home represents less than ten percent of all families in America.

It is therefore evident that the future of work will be characterized by dual-career/dual-earner couples. It is important to distinguish between dual-career couples and dual-earner couples. Some researchers refer to it as an interchangeable concept, whereas others draw a clear distinction. Rapoport and Rapoport (1973, p. 152) distinguished between the terms dualcareer families and dual-earner families as follows: "Dual-career families are differentiated from dual-earner families by the fact that the first is not economically inspired and the wife works in a position that requires commitment and has a developmental character". Dual-career families can therefore be defined as " the type of family in which both heads of households pursue careers and at the same time maintain a family life together" (Rapoport \& Rapoport, 1976, p. 18). Greenhaus and Callanan (1994, p. 252) stated that to be classified as dual-career couples, couples need not be married or have professional jobs that are emotionally absorbing. Guterman in Muchinsky, Kriek and Schreuder (1998, p. 263) defined dual-career couples as follows: "Two individuals who both work, are committed to their relationship, with or without children, and whose work situations influence decisions concerning their work and family life, can be identified as a working couple." For the purpose of this research the focus will be on dual-career couples.

There are various reasons for people engaging in a dual-career situation. Greenhaus (1987, p. 217) reported some of the reasons as the need for a higher living standard and the need to customize a career path. Hertz (1986, p. 6) identified self-efficacy as one of the major reasons for both spouses engaging in a career. Due to the economic pressure of inflation and the social need to develop one's own identity, the quality of living of dualcareer couples can be enriched (Duxbury \& Higgins, 1991, p. 60). Muchinsky et al. (1998, p. 263) included benefits such as higher income, the opportunity to develop beyond gender-role stereotypes and having equal power. They indicate the importance of childrens' development if they are exposed to a dual-career relationship: children develop a more positive selfconcept, have financial security and the opportunity to grow independent. Rapoport (1976, p. 398) also suggested that dualcareer marriages have the potential for greater equality in task performance and in responsibility for each spouse.

Weingarten (1978, p. 113) argued that although dual career couples improve their living standards and self-esteem, several problematic issues can also be identified. As such the difficulty to create and maintain a balance between work and family may result in role conflict and role ambiguity (Davidson \& Cooper, 1983; Kossek \& Ozeki, 1998, p. 139). Furthermore, role conflict (in work and family life) refers to an appraisal of conflicting demands within one role, or between different roles, while role ambiguity denotes uncertainty about expectations associated with a particular role (Kossek \& Ozeki, 1998, p. 139). Morrison and Clements (1997, p. 307) stated that dual career couples experience higher levels of role conflict and role ambiguity than traditional families. Role conflict and role overload are determinants of work-family conflict and can lead to burnout and marital dissatisfaction (Bacharach, Bamberger \& Conley, 1991, p. 41). Role conflict in turn, leads to inter-role conflict. Inter-role conflict is described as the phenomenon where "compliance with one role is incompatible with the full compliance with another role" (Thomas \& Ganster, 1995, p. 7).

The consequences of multiple roles may lead to role overload. Leslie and Leslie (1980, p. 322) indicated that women tend to have greater role overload than men. Women also tend to have identity problems if they believe that their current life-style is not consistent with their earlier gender-role socialization (Greenhaus, Callanan \& Godshalk, 2000, p. 300). Greenhaus et al. (2000, p. 384) analysed the issues of jealousy and competition among dual-career couples, and found that dualcareer couples have a greater propensity to compete with each other than traditional couples. In the traditional domain both spouses experience satisfaction, since the husband shows competence at work and the wife masters her domestic chores. When both spouses are employed one spouse may also become more successful than the other (Hall \& Hall, 1978, p. 58). Greenhaus et al. (2000, p. 300) indicated that husbands become threatened if their wives are more successful. They postulate that women who are more successful at work, experience less marital satisfaction. This suggests that their success causes resentment with their husbands. It is important to acknowledge that competition and jealousy can threaten the stability of a marriage. Hence, this may result in a breakdown in communication since partners become reluctant to share jobrelated issues with their spouses.

The above discussion underscores the complexity of issues underlying the dynamics of dual-career relationships. One of the most fundamental issues in a dual-career relationship can therefore be seen to be the challenge to create and maintain a balance between work and family. The inability to maintain this balance may lead to marital dissatisfaction, which in turn is a manifestation of work-family conflict.

\section{Work-family conflict}

Work and family are two of the most important realms of adult life. Work and family were traditionally studied as two separate, independent domains. It is now recognised that the existence of a reciprocal relationship is beyond dispute. In other words, work and family are inseparable as the organisation determines the social status and financial position of the family members. The family also plays an important role in providing support to the organisation's employees in stressful times. Sumer and Knight (2001, p. 653) refer to this relationship as a "spillover". They indicated that a spillover can be either positive or negative, i.e. being in a family situation can make work life more problematic and complex, or it can enhance work life. It is important that organisations address the issues of work-family conflict, since conflict and stress can increase as employees experience difficulties in balancing their work and family lives. The implications for their employers are productivity losses and absenteeism due to accidents caused by increased levels of fatigue (Ganster \& Schaubroeck, 1991, p.237; Greenhaus \& Beutell, 1985, p. 80; Thomas \& Ganster, 1995, p. 6).

Most research conducted on work-family conflict has been based on analyses of the influence of family on work, but not vice versa (Rapoport \& Rapoport, 1976, p.376). Greenhaus and Beutell (1985, p. 77), for example did not address this reciprocal relationship. Frone et al. (1992, p. 66) focused on the impact that work has on the family and the interface thereof, and concluded that couples reported almost three times more work to family conflict than family to work conflict. This finding is consistent with Schaubroeck's (1990) finding that the conflict relationship between work and family may be examined in the context of a reciprocal relationship.

Greenhaus et al. (2000, p. 290) defined work-family conflict as follows: "Work-family conflict exists when pressures from work and family roles are mutually incompatible, such as when participation in one role is made more difficult by virtue of participation in another role." Dual-career couples are caught in a bind in two ways. Firstly, they must place a high priority on work in order to achieve economic rewards and social status for themselves and for their families. Secondly, they have to make sacrifices, which usually means spending less time with their families. 
The types of conflict that they can experience are time-based conflict, strain-based conflict and behaviour-based conflict. This can be linked with inter-role conflict where one role is incompatible with another. Time-based conflict is experienced when roles compete for time. Time spent in the one role cannot be spent in the other role, for example out-of-town business meetings can conflict with family dinners (Greenhaus, 1987, p. 212; Greenhaus et al., 2000, p. 290). Bacharach et al. (1991, p. 41) and Greenhaus and Beutell (1985, p. 77) agreed that time devoted in one role makes it difficult to fulfill requirements in another role. Strain-based conflict exists when the strain produced by one role affects performance in another role (Greenhaus, 1987, 212; Netemeyer et al., 1996, p. 400). Greenhaus et al. (2000, p. 291) indicated that work stressors can produce strain symptoms like tension, irritability, fatigue and depression. Behaviour-based conflict occurs when the behaviour in one role is not necessarily appropriate for the other role (Netemeyer et al., 1996, p. 400). For example, a person needs to be sensitive and caring at home, but at work an assertive, logical and impersonal approach may be required. The type of behaviour reflected at work might obviously be inappropriate at home. It is therefore postulated that couples who have information on the type of behaviour that is expected of their partner at work, may enhance their understanding of certain behaviours of their partners and even display more empathy when required.

The strain of trying to balance work and family may lead to dissatisfaction (Duxbury \& Higgins, 1991, p. 60; Frone et al., 1992, p. 66; Thomas \& Ganster, 1995, p. 7) and depression (Goff, Mount \& Jamison, 1990, p. 795). Work-family conflict may also lead to health risks and suicide (Duxbury \& Higgins, 1991, p. 60; Jones \& Fletcher, 1996, p. 89). Jones and Fletcher (1993, p. 883 ) discussed the importance of communication of work issues with partners. They found that a fluctuation in workrelated daily stressors leads to mood fluctuation by both spouses. Bumpus, Crouter and McHale (1999, p. 465) supported these findings and the impact of daily stressors on children. They further reported in this regard that children's well-being is influenced by their parents' moods. Repetti and Wood (1997, p. 90) found that dual-career couples spend less time with their children and the children normally do not know what their parents do during the day.

Bumpus et al. (1999, p. 465) and Crouter and Manke (1997, p. 64) found that it was important for both parents to explore their work conditions and link it to family processes. Bumpus et al. (1999, p. 467) emphasised the importance of knowledge parents should have about their children. However, they do not discuss the importance of individual spouses having knowledge about each other's work or routine during the day.

While research focuses mainly on the negative aspects of workfamily relationships, Ridley (1973) reported a positive side. He indicated that people would have a greater understanding of each other's needs if they both work, since they can relate to the demands imposed by the work sphere. The question to be raised here is whether this mutual understanding occurs naturally, and whether it can be enhanced by increased communication.

Thomas and Ganster (1995, p. 6) found that employees who perceive that they have adequate knowledge regarding their partners' work and personal matters, experience less conflict within the relationship. They associated a lack of knowledge with more job dissatisfaction, depression, somatic complaints and higher blood cholesterol. It seems that a lack of sharing of job-related information, leads to a decrease in marital satisfaction as well as job satisfaction. It can be postulated that couples that have information regarding their partners' jobs, will have insight into the different roles they have to fulfill within their working environment and their family life. Couples who do not have information regarding their spouses' jobs may not understand the different roles required by their spouses and as a result experience more intra-marital conflict.
Balancing work and family life imposes certain demands on couples. Guterman (in Muchinsky et al., 1998, p. 263) mentioned a few of these demands:

- Quality communication, spending enough time on intimate discussions about themselves as individuals and their relationships.

- Setting priorities with regard to time spent on work, managing the home, childcare, leisure and other activities.

- Clarifying values, e.g. work values such as challenge, growth, opportunity, security, recognition, power and prestige, and life values concerning hobbies, leisure, continued learning, religion and being part of society.

- Examining roles and their respective relative weights, such as the roles of provider, nurturer, homemaker, and bill payer.

- Managing stress by identifying the sources, attempting to reduce the sources, examining one's responses to stress, and taking the responsibility to manage one's own stress.

Dealing with these demands clearly requires continuous communication. Baron and Byrne (1991, p. 386) identified inadequate communication to be one of the most prevalent sources of conflict among employees and families.

\section{Communication}

"Communication can be defined as the transfer of information that is meaningful to those involved" (Byars \& Rue, 1991, p. 498). Noller and Fitzpatrick (1990, p. 835) identified inadequate communication to be a major contributive factor of marital dissatisfaction. Klinetob and Smith (1996, p. 945) also suggested poor communication or a lack thereof to be an important source of distress in work and family life. Communication can either be effective (competent) or ineffective (negative). Competent communication is the ability to reveal private thoughts and feelings about the self with a partner (Kaney \& Bradbury, 1995, p. 5). Negative communication includes criticism, excessive complaining and sarcastic remarks.

Hertz (1986, p. 76) showed that it is important for dual-career couples to develop a different style of communication from that found in the traditional marital relationships. Husbands and wives with careers spend most of their time engaged in similar activities, which though mostly involving different types of expertise, share a rhythm and a structure. She concluded that dual-career couples have a different level of understanding about each other's lives, a level that is intimate and empathic. This statement underscores the importance of communication in dual-earner relationships or where couples do not have the same careers. Hertz (1986, p. 77) described the communication of dual-career couples as "similarity in partners' talk". However, since people may tend to think their spouses will not understand their work, especially when specialist knowledge is required, they may not talk about their jobs. Franzoi (1996, p. 375) found that most relationships end due to a lack of or breakdown in communication. Blias, Sabourin, Boucher and Vallerand (1990, p. 1022) indicated that women are more likely than men to engage in emotional sensitivity, keeping the avenues open for communication and maintaining couple satisfaction. Pepitone-Rockwell (1980, p. 200) also emphasised the importance of open communication. He believed that communication fosters cooperation, understanding and mutuality and paves a way to compromising and negotiation. Communication can lead to a fulfillment of needs and the willingness to meet the other's needs.

Open communication has advantages and disadvantages. The advantages are greater direct support for each other, greater potential for respect, stemming both from a spouse's ability to deliver an informed opinion as well as from a greater understanding of each other. A qualitative study by Hertz (1986, p. 80) revealed that most spouses know what the other is doing on a day-to-day basis and that they respect each other's careers. Disadvantages include that talking about work has the potential for creating competition for status between spouses or about 
who knows best. Many couples solve these problems by carving out distinct areas of expertise for each other. This delineation limits communication however, and prevents them from getting close to their spouse's world outside their family lives.

Given the above, the question to be answered is whether a lack of information between spouses about their partners' jobs contributes to work-family conflict. It is hypothesised that the more inadequate or incomplete the information regarding the partners' work content and work-related experiences, the more conflict is experienced in their marriages. It is postulated that dual-career couples that disclose job-related information to their partners about their daily routine and work issues will experience less marital conflict.

\section{METHOD}

\section{Respondents}

To answer the research question it was necessary to use information obtained from married couples or couples who cohabit. It is acknowledged that couples who cohabit may not necessarily be of opposite gender, however, for the purpose of this research, it was decided to involve married couples only or couples of opposite genders who cohabit.

To clearly define the population, three criteria were established. First, respondents had to be married or in cohabitation for more than three years prior to taking part in the research project. Second, all respondents had to be childless (to exclude extraneous variables that could have an impact on conflict experienced by dual-career couples). Finally, both should have been in professional jobs with at least one partner working in a corporate environment.

Employees from various departments at the head office of a major financial institution were approached to assist the researcher in identifying dual-career couples that met the criteria for inclusion. The final sample consisted of 80 dualcareer couples. The population groups consisted of $50 \%$ whites, $25 \%$ coloureds, $20 \%$ blacks and $5 \%$ Asians.

The mean age of the males in the sample was 33.03 years $(S D=5.66)$ and the mean age of the females was 30.69 years $(S D=4.71)$. The couples had been married or in cohabitation for an average of 4.36 years $(S D=2.46)$. The respondents were predominantly from a white-collar environment and operated in diverse functional areas (e.g. including accounting, managerial, human resources, marketing and IT). All of the respondents were educated beyond high school level (except for one female).

\section{Measuring instruments}

The aim was to develop a measuring instrument that could provide information on areas that couples perceived to contribute to marital conflict in their marriages and have an impact on the quality of their relationships. In order to achieve both face and content validity of the questionnaire, interviews were conducted with individuals and small groups in order to obtain data about sources of possible conflict within a marriage. These individuals and small groups formed part of the total population used in the study. The Work Perception Questionnaire (WPQ) was developed using the information obtained during discussions with focus groups.

The questionnaire consisting of four scales was compiled, namely:

- a biographical scale,

- a scale measuring perceptions and feelings about one's work,

- a scale on factual information about one's job, and

- a scale measuring perceptions about the extent of marital conflict in one's marriage.
Biographical Scale. Questions regarding gender, age, education, job type and area in which the respondents lived and worked, were included in this questionnaire.

Job Perception Scale. This scale consisted of 38 questions. Each item was scored on a 7-point scale measuring from 1 (strongly disagree) to 7 (strongly agree) or from 1 (not at all) to 7 (to a large extent). Examples of items in this scale included "in your workplace, during an average working day, you focus a lot of your energy on i) repetitive tasks, ii) training others, iii) receiving instructions, iv) giving instructions, v) conversing with people on the phone and vi) finding creative ways of working".

Factual Job Information Scale. The 15 items in this scale measured the factual knowledge that the spouses had of their partners' jobs. Examples of items in this scale included questions such as:

How many colleagues do you have?

How many people do you report to?

How many days do you take work home?

The items of the Job Perception Scale and the Factual Information Scale were compiled solely for the purpose of measuring differences between partners on an item-by-item basis. As a result conventional psychometric indices such as total scale reliabilities were not relevant for these scales. For the Marital Conflict Scale, however, internal consistency reliabilities were computed, because total scores were used for the purpose of comparison.

Marital Conflict Scale. This scale measured the conflict experienced by the couples. It consisted of 13 items. An example of an item in this scale is: To what extent do you experience the following types of conflict in your marriage: financial issues, working hours, workload, work-related social activities and inadequate communication? Cronbach's coefficient alpha was computed for males and females separately and together. The coefficient alpha for males was 0.77 , for females 0.75 , and for the combined group 0.76 . The means, standard deviations and alpha coefficients are reported in Table 1.

TABLE 1

DESCRIPTIVE STATISTICS AND INTERNAL CONSISTENCY Reliabilities of THE Marital Conflict Scale

\begin{tabular}{lcccc}
\hline & $M$ & $S D$ & $N$ & Cronbach's alpha \\
\hline Female about Self & 39,38 & 9,30 & 80 & 0,75 \\
Male about Self & 39,89 & 9,52 & 80 & 0,77 \\
Total & 39,63 & 18,35 & 160 & 0,76 \\
\hline
\end{tabular}

Each member of a couple or pair of respondents had to complete two versions of the entire questionnaire. The respondents had to complete a questionnaire about their own jobs and marital conflict experienced. Thereafter they had to complete an adapted version about what they perceived to be true about their spouses' jobs and marital conflict experienced. In other words, for every pair of the dual-career couples, four questionnaires were completed, namely:

- Female about Self

- Female about Male spouse's job

- Male about Self

- Male about Female spouse's job

\section{Procedure}

The respondents were recruited from corporate environments through personal contacts and associates, in other words, an accidental sample was used. The respondents completed the questionnaires in the comfort of their own homes or that of a 
family member or friend. The researcher was present throughout the completion of the questionnaires. The purpose of the study was explained and some background on previous research was provided. Each respondent completed two questionnaires (one on how they experienced their own work and marriage and one on what they perceived to be true about their spouses' experience of work and marriage). The respondents were not allowed to discuss the questionnaire while completing it. They were also seated not to face each other so that they could not see one another's responses or facial expressions. They were assured that their responses to the questionnaire would be kept confidential.

\section{RESULTS}

The degree of ignorance that individuals exhibit about their partners' jobs was assessed by studying the differences between the perceptions reported by the partners themselves and the views that the individuals have about their partners' jobs. For example, the difference between what male partners believed about themselves and what their female partners perceived to be true for these male partners, constituted the degree of ignorance or disagreement.

The degree of disagreement between the partners of a couple was obtained by calculating

(a) the sum of the absolute values of the differences between the Female about Self and the Male about Female spouse's job [Male about Self and Female about Male spouse's job] scores on each item of the Job Perception Scale, and

(b) the mean sum of the absolute values of the differences between the Female about Self and the Male about Female spouse's job [Male about Self and Female about Male spouse's job] scores on each item of the Factual Job Information Scale divided by its standard deviation. Since each item was measured on a different scale, transformations were necessary.

The means, standard deviations, skewness and kurtosis of the differences computed in (a) are reported in Table 2 and the means, standard deviations, skewness and kurtosis of the differences computed in (b) are reported in Table 3.
TABLE 2

DESCRIPTIVE STATISTICS OF THE DEGREE OF DISAGREEMENT SCORES on the Job Perception Scale (N=79)

\begin{tabular}{lcccc}
\hline & $M$ & $S D$ & Skewness & Kurtosis \\
\hline Female about Self - Male about & 41,19 & 14,05 & 1,14 & 2,46 \\
Female spouse's job & & & & \\
Male about Self - Female about & 41,34 & 14,11 & 1,04 & 0,80 \\
Male spouse's job & & & & \\
\hline
\end{tabular}

TABLE 3

DESCRIPTIVE STATISTICS OF THE DEGREE OF DISAGREEMENT SCORES ON THe Factual Information Scale $(\mathbf{N}=\mathbf{8 0})$

\begin{tabular}{lcccc}
\hline & $M$ & $S D$ & Skewness & Kurtosis \\
\hline Female about Self - Male about & 0,56 & 0,38 & 0,74 & $-0,33$ \\
Female spouse's job & & & & \\
Male about Self - Female about & 0,51 & 0,48 & 2,16 & 5,53 \\
Male spouse's job & & & & \\
\hline
\end{tabular}

The means, standard deviations and degree of positive skewness in Table 2 is similar for the two sets of results, but the Females about Self/Male about Female spouse's job showed a more leptokurtic distribution than the Male about Self/Female about Male spouse's job distribution. For the Factual Information Scale (see Table 3) the Male about Self/Female about Male spouse's job distribution was markedly more positively skewed and leptokurtic than the Female about Self/Male about Female spouse's job distribution.

To test the hypothesised relation between marital conflict and degree of ignorance about the jobs of the respective partners, the intercorrelations between the Marital Conflict Scale and the various disagreement variables were computed. The intercorrelations between the disagreement scores relating to the Job Perception Questionnaire and the Marital Conflict Scale

TABLE 4

Correlations between the disagreement scores of the Job Perception Scale and the Marital Conflict Scale (N=80)

Job Perception Scale

Marital Conflict Scale

Female about Self - Male Male about Self - Female Female about Self Female about Male spouse Male about Self Male about Female spouse about Female spouse's job about Male spouse's job
Job Perception Scale

Female about Self - $\quad 1,00$

Male about

Female spouse's job

Male about Self -

$0,60(0.000)$

1,00

Female about

Male spouse's job

Marital Conflict Scale

Female about Self

Female about

Male spouse

Male about Self

Male about

Female spouse

$\begin{array}{ll}0,16(0,161) & 0,17(0,133) \\ 0,21(0,065) & 0,31(0,005) \\ 0,37(0,001) & 0,34(0,002) \\ 0,28(0,014) & 0,25(0,026)\end{array}$

$0,17(0,133)$

1,00

$0,66(0,000) \quad 1,00$

$0,46(0,000) \quad 0,70(0.000)$

$0,58(0,000) \quad 0,55(0.000)$
1,00

$0,71(0,000) \quad 1,00$

Two-tailed $p$ values are given in brackets 
measures are reported in Table 4. Similarly, the correlations between the disagreement scores relating to the Factual Information Questionnaire and the various Marital Conflict Scale measures are reported in Table 5.

\section{TABLE 5}

CORRELATIONS BETWEEN THE DISAGREEMENT SCORES of THE Factual Information Scale and the Marital Conflict SCale $(\mathbf{N}=\mathbf{8 0})$

\begin{tabular}{lll}
\hline & $\begin{array}{l}\text { Factual Information Scale } \\
\text { Female about Self - Male } \\
\text { about Female spouse's job }\end{array}$ & $\begin{array}{l}\text { Male about Self - Female } \\
\text { about Male spouse's job }\end{array}$ \\
\hline $\begin{array}{l}\text { Factual Information Scale } \\
\text { Female about Self - } \\
\text { Male about }\end{array}$ & 1,00 & \\
$\begin{array}{l}\text { Female spouse's job } \\
\text { Male about Self - }\end{array}$ & $0,44(0,000)$ & 1,00 \\
$\begin{array}{l}\text { Female about } \\
\text { Male spouse's job }\end{array}$ & \\
$\begin{array}{l}\text { Marital Conflict Scale } \\
\text { Female about Self }\end{array}$ & $0,12(0,303)$ & $0,15(0,194)$ \\
$\begin{array}{l}\text { Female about } \\
\text { Male spouse }\end{array}$ & $0,26(0,022)$ & $0,31(0,006)$ \\
$\begin{array}{l}\text { Male about Self } \\
\text { Male about }\end{array}$ & $0,24(0,034)$ & $0,28(0,013)$ \\
Female spouse & $0,29(0,011)$ & $0,22(0,048)$ \\
\hline
\end{tabular}

Two-tailed $p$ values are given in brackets

The results in Table 4 indicate statistically nonsignificant correlations of Female about Self (on the Marital Conflict Scale) with Female about Self - Male about Female spouse's job and with Male about Self - Female about Male spouse's job on the Job Perception Scale. The correlations were $0.16(p=0.161)$ and 0.17 ( $p=0.133)$ respectively. This implies that for females the hypothesis of a correlation between degree of marital conflict experienced and degree of ignorance as measured by the Job Perception Scale does not hold. In contrast, statistically significant correlations of Male about Self (on the Marital Conflict Scale) with Female about Self - Male about Female spouse's job and with Male about Self Female about Male spouse's job on the Job Perception Scale were obtained. The correlations were $0.37(p=0.001)$ and $0.34(p=0.002)$ respectively. This implies that for males the hypothesis of a correlation between degree of marital conflict experienced and degree of ignorance was supported.

The intercorrelations on the Marital Conflict Scale (see Table 4) were all statistically significant. In other words, females and males were in agreement about the degree of conflict in their marriages. The two highest correlations were $0,71 \quad(p<0.001)$ between Male about Self and Male about Female spouse's job and $0.70(p<0.001)$ between Female about Male spouse's job and Male about Self on the Marital Conflict Scale respectively. This shows (i) that female partners perceived the conflict experienced by their male partners accurately and (ii) that male partners presumed that their female partners experienced the same degree of conflict as themselves. The male partners were therefore to a lesser degree able to recognise the conflict experienced by their female partners.

The results in Table 5 indicate statistically nonsignificant correlations of Female about Self (on the Marital Conflict Scale) with Female about Self - Male about Female spouse's job and with Male about Self - Female about Male spouse's job on the Factual Information Scale. The correlations were $0.12(p=0.303)$ and $0.15(p=0.194)$ respectively. This implies that for females the hypothesis of a correlation between degree of marital conflict experienced and degree of ignorance regarding factual job information does not hold.
In contrast, statistically significant correlations of Male about Self (on the Marital Conflict Scale) with Female about Self - Male about Female spouse's job and with Male about Self - Female about Male spouse's job on the Factual Information Scale were obtained (see Table 5). The correlations were $0.24(p=0.034)$ and $0.28(p=0.013)$ respectively. This implies that for males the hypothesis of a correlation between degree of marital conflict experienced and degree of ignorance about factual job information was supported.

\section{DISCUSSION}

The results demonstrate that the relationship between communication of job-related information among dual-career couples and work-family conflict is rather complex.

One of the most important results of the study and one that provides a context for interpreting other results - was the finding that male partners experienced more conflict than their female partners if they did not have adequate information regarding their female partners' jobs (indicated in Tables 4 and 5).

There was a moderate correlation between the conflict experienced by female partners and a lack of adequate jobrelated information, i.e. female partners did not experience more conflict if their male partners did not disclose job-related information to them. However, there was a significantly positive correlation between the conflict experienced by male partners' in their marriages and lack of job-related information regarding their female partners jobs. The stated hypothesis is therefore accepted for male partners. The experience of the male partners tends to be consistent with the findings of Thomas and Ganster (1995), namely that employees who did not have adequate knowledge about their spouses' jobs, experienced more conflict.

The results shown on the Marital Conflict Scale (see Table 4) were all significant and indicated that female partners had perceived the conflict experienced by their male partners more accurately than their male partners perceived the conflict they (the female partners) had experienced. It appears that the male partners perceived their own conflict accurately. The assumption can be made that females are more likely than males to engage in emotional sensitivity and keeping the way open for quality communication as stated by Blias et al. (1990).

The results obtained by the Job Perception Scale and the Factual Information Scale correlated significantly with the Marital Conflict Scale and produced similar results for each questionnaire.

The correlations between the Factual Information Scale and the Marital Conflict Scale (see Table 5) showed that the male partners also experienced more conflict if they did not have factual information regarding their female partners' jobs. For the female partners the corresponding correlation was not significant. It can therefore be postulated that males experience more conflict when their female partners do not disclose jobrelated information, but not the other way around. Perhaps this is due to the fact that females are perceived to be more expressive and self-disclosing as implied by Blias et al. (1990). This is in contrast with the findings of Hertz (1986) that indicate that dual-career couples share on a level that is more intimate and empathetic. The results obtained indicate that the population used did not share factual job-related information between partners.

Male partners experienced a high degree of conflict if their degree of ignorance regarding their female partners' jobs was also high. This is consistent with Thomas and Ganster (1995) who indicated that spouses who have knowledge regarding their spouses' jobs, experience less conflict in their marriages. 
The results also indicated that male partners experienced more conflict in their marriages if the degree of ignorance (by their female partners) regarding their (the male partners) jobs was large. It appears that the male partners had an expectation that their female partners should have more knowledge regarding their (the male partners') jobs.

The question posed earlier in the article of whether the understanding that spouses have about one another's jobs occur naturally or whether it can be enhanced through adequate communication, can therefore be answered in view of the above results. It appears that adequate communication may enhance knowledge regarding one another's jobs. Noller and Fitzpatrick (1990) also indicated that adequate communication might lead to greater marital satisfaction. The results suggest that couples that communicate with one another about their job-related activities may experience less conflict in their marriages.

A limitation of the study could be the fact that the sample consisted mostly of respondents in the financial sector. Another limitation was the fact that the questionnaire was based on selfreport, and therefore the results were based on the assumption that the couples' perceptions of each other were accurate.

The study may be beneficial for organisations to become aware of the importance of the family on work. Organisations can assist dual-career couples by getting employees' spouses more involved in certain activities and encourage employees to discuss job-related issues at home. Organisations can make use of the information obtained in the research by adding these findings into policies and courses, for example life mastery workshops, diversity workshops and management workshops.

Career counselors may highlight the importance of the family to an individual when they make career decisions. They can also make use of the information obtained in the study by advising employees that certain preferred behaviour at work may not necessarily be accepted at home and vice versa.

Marriage counselors may use the results obtained to help couples eliminate or emphasise the critical role of communication in their marriage. They can assist couples to adopt more successful methods of constructive communication styles. Counselors can suggest joint career counseling to observe how work and family can best be balanced based on individual needs and developmental needs of the couple. Marriage counselors can also encourage couples to share work-related friends and activities to develop a supportive social network. Counselors can educate couples to be more expressive and share more work-related issues in counseling sessions. They can encourage couples to have informal "debriefing sessions" or conversations about work, after work. These conversations will allow spouses to share their frustrations and successes from the day's work and provide marital support for each other. The quality and not the quantity of time spent talking is a crucial feature.

The findings of the research may also be utilised at tertiary education level as part of life orientation skills. It will be beneficial to highlight the importance of communication in a relationship to students to alleviate the 'reality shock' at a later stage. This may enhance their communication patterns and development decisions.

Future research on this topic may focus on replicating the study by investigating dual-career couples with children. The aim of the research could be to identify whether a lack of information regarding their parents' jobs have an impact on children. It would be interesting to establish whether couples that cohabit share less job-related information than couples that are married and whether they (couples in cohabitation) experience less conflict. A further study could be to investigate whether couples of the same gender that cohabit experience less conflict than couples of opposite gender.

\section{ACKNOWLEDGEMENT}

The authors would like to thank Riëtte Eiselen and Janes du Toit of Statcon at RAU for their professional service and valuable contribution regarding the data analysis of this project.

\section{REFERENCES}

Bacharach, S.B., Bamberger, P. \& Conley, S. (1991). Work-home conflict among nurses and engineers: Mediating the impact of role stress on burnout and satisfaction at work. Journal of Organisational Behaviour, 12, 39-53.

Baron, R.A. \& Byrne, D. (1991). Social psychology: Understanding human interaction ( $6^{\text {th }}$ ed). Boston: Allyn \& Bacon.

Blias, M.R., Sabourin, S., Boucher, C. \& Vallerand, R.J. (1990). Toward a motivational model of couple happiness. Journal of Personality and Social Psychology, 59, 1021-1031.

Bumpus, M.F., Crouter, A.C. \& McHale, S.M. (1999). Work demands of dual -earner couples: Implications for parents' knowledge about children's daily lives in middle childhood. Journal of Marriage and Family, 61, 456-475.

Byars, L.L. \& Rue, L.W. (1991). Human resource management. Boston: Irwin.

Carrell, M.R., Elbert, N.F. \& Hatfield, R.D. (2000). Human resource management: Strategies for managing a diverse and global workforce (6 $6^{\text {th }}$ ed). Orlando: Dryden.

Crouter, A. C. \& Manke, B. (1997). Development of a typology of dual-earner families: A window into differences between and within families in relationships, roles and activities. Journal of Family Psychology, 11, 62-75.

Davidson, M.J. \& Cooper, C.L. (1983). Stress and the woman manager. Oxford: Martin Robertson.

Duxbury, L.E. \& Higgins, C.A. (1991). Gender differences in work-family conflict. Journal of Applied Psychology, 76(1), 60-74.

Franzoi, S.L. (1996). Social psychology. Madison: Brown \& Benchmark.

Frone, M.R., Russel, M. \& Cooper, M.L. (1992). Antecedents and outcomes of work-family conflict: Testing a model of the work-family interface. Journal of Applied Psychology, 77(1), 65-76.

Gabarro, J.J. (1992). Managing people and organisations. Boston: Harvard.

Ganster, D.C. \& Schaubroeck, J. (1991). Work stress and employee health. Journal of Management, 17, 235-271.

Goff, S.J., Mount, M.K. \& Jamison, R.L. (1990). Employer supported childcare, work/family conflict, and absenteeism: A field study. Personnel Psychology, 43, 793-809.

Greenhaus, J.H. (1987). Career management. San Diego: Dryden.

Greenhaus, J.H. \& Beutell, N.J. (1985). Sources of conflict between work and family roles. Academy of Management Reviews, 10, 76-88.

Greenhaus, J.H. \& Callanan, G.A. (1994). Career management (2nd ed.). Orlando: Dryden.

Greenhaus, J.H., Callanan, G.A. \& Godshalk, V.M. (2000). Career management ( $3^{\text {rd }}$ ed). Orlando: Dryden.

Hall, F.S. \& Hall, D.T. (1978). Dual-careers: how do couples and companies cope with problems. Organisational Dynamics, 6 (4), 57-77.

Hertz, R. (1986). More equal than others: women and men in dualcareer marriages. London: University of California Press.

Jones, F. \& Fletcher, B.C. (1993). An empirical study of occupational stress transition. Human Relations, 46, 881-903. 
Jones, F. \& Fletcher, B.C. (1996). Taking work home: A study of daily fluctuations in work stressors, effects on moods and impacts on marital partners. Journal of Occupational and Organisational Psychology, 69(1), 89-106.

Karney, B.R. \& Bradbury, T.N. (1995). The longitudinal course of marital quality and stability. Psychological Bulletin, 118, 3-34.

Klinetob, N.A. \& Smith, D.A. (1996). Demand-withdraw communication in marital interaction: Tests of interspousal contingency and gender role hypotheses. Journal of Marriage and Family, 58, 945-957.

Kossek, E.E. \& Ozeki, C. (1998). Work-family conflict, policies and the job-life satisfaction relationship. A review and directions for organisational behaviour- Human Resources Research. Journal of Applied Psychology, 83(2), 139-149.

Leslie, G.R. \& Leslie, E.M. (1980). Marriage in a changing world ( $2^{\text {nd }}$ ed). Brisbane: Wiley.

Morrison, D.L. \& Clements, R. (1997). The effect of one partner's job characteristics on the other partner's distress: A serendipitous, but naturalistic, experiment. Journal of Occupational and Organisational Psychology, 70, 307-324.

Muchinsky, P.M., Kriek, H.J. \& Schreuder, A.M.G (1998). Personnel Psychology. Johannesburg: Thomson.

Netemeyer, R.G., Boles, J.S. \& MacMurrian, R. (1996). Development and validation of work-family conflict and family-work conflict scales. Journal of Applied Psychology, 81 (4), 400-410.

Noller, P. \& Fitzpatrick, M.A. (1990). Marital communication in the eighties. Journal of Marriage and the Family, 52, 832-843.
Pepitone-Rockwell, F. (1980). Dual career couples. London: Sage. Rapoport, R. \& Rapoport, R.N. (1973). Dual-career families (2 ${ }^{\text {nd }}$ ed.). Harmondsworth, England: Penguin.

Rapoport, R. \& Rapoport, R.N. (1976). Dual-career families. Harmondsworth, England: Penquin.

Repetti, R.L. \& Wood, J. (1997). Effects on daily stress at work on mothers' interaction with pre-schoolers. Journal of Family Psychology, 11, 90-108.

Ridley, C.A. (1973). Exploring the impact of work satisfaction and involvement on marital interaction when both partners are employed. Journal of Marriage and Family, 35(1), 229-237.

Schaubroeck, J. (1990). Investigating reciprocal causation in organisational research. Journal of Organisational Behaviour, $11,17-28$

Smith, C.R. (1997). Career transitions of dual-career couples: an empirical study. Career development International, 2(5), 229-237.

Sumer, H.C. \& Knight, P.A. (2001). How do people with different attachment styles balance work and family? A personality perspective on work-family linkage. Journal of Applied Psychology, 86(4), 653-663.

Thomas, L.T. \& Ganster, D.C. (1995). Impact on familysupportive work variables on work-family conflict and strain: A control perspective. Journal of Applied Psychology, $80(1), 6-15$

Weingarten, K. (1978). The employment pattern of professional couples and their distribution of involvement in the family. Psychology of Women Quarterly, 3, 43-53. 